\title{
Nitrogen fertilization of self-seeding Italian ryegrass: effects on plant structure, forage and seed yield
}

\author{
Alberto Bohn ${ }^{1}$ Gabriel Streck Bortolin ${ }^{2 *}$ (D) César Iván Suárez Castellanos ${ }^{1}$ (D) \\ Bruna Barreto dos Reis $^{1}$ Anna dos Santos Suñé ${ }^{(\mathbb{D}}$ Joice Fernanda Lübke Bonow ${ }^{1}$ (D) \\ Carlos Eduardo da Silva Pedroso ${ }^{1}$ (D) Andréa Mittelmann ${ }^{3}$ (D)
}

'Departamento de Fitotecnia, Faculdade de Agronomia Eliseu Maciel, Universidade Federal de Pelotas (UFPel), Capão do Leão, RS, Brasil. ${ }^{2}$ Programa de Pós-graduação em Ciência \& Tecnologia de Sementes, Departamento de Fitotecnia, Faculdade de Agronomia Eliseu Maciel, Universidade Federal de Pelotas (UFPel), 96050-500, Capão do Leão, RS, Brasil. E-mail: gabrielbortolin91@gmail.com. "Corresponding author. ${ }^{3}$ Empresa Brasileira de Pesquisa Agropecuária, Centro de Pesquisa Agropecuária de Clima Temperado, Estação Experimental de Terras Baixas, Pelotas, RS, Brasil.

\begin{abstract}
This study aimed to evaluate the effect of different levels of self-seeding Italian ryegrass (Lolium multiflorum Lam.) and nitrogen rates - applied additionally after two defoliations - on plant structure, in forage and seed yield. Levels of self-seeding were classified as very high (777 $\left.\mathrm{kg} \mathrm{ha}^{-1}\right)$, high (736 $\left.\mathrm{kg} \mathrm{ha}^{-1}\right)$, intermediate (624 $\left.\mathrm{kg} \mathrm{ha}^{-1}\right)$, and low (234 $\left.\mathrm{kg} \mathrm{ha}^{-1}\right)$. Populations were fertilized with zero, 20.25 , 40.50 , and $60.75 \mathrm{~kg} \mathrm{ha}^{-1}$ of supplemental nitrogen applied after two defoliations; respectively, in very high, high, intermediate, and low levels. Higher levels of self-seeding promoted greater forage yield and uniformity of vegetation structure. Number of fertile tillers and number of seeds per plant have benefited by the combination of high self-seeding and supplemental nitrogen fertilization. Despite influencing the uniformity and amount of forage obtained in two defoliations, the very high and low self-seeding levels did not differ in Italian ryegrass seed production. However, linear addition for this same variable was obtained with the inclusion of supplemental nitrogen fertilization. In pastures from low and intermediate self-seeding levels, total dry mass increases linearly with the levels of nitrogen fertilization assessed in this research. Key words: (Lolium multiflorum Lam.), natural reseeding, nitrogen rates, seed yield components.
\end{abstract}

Adubação nitrogenada em azevém anual, proveniente de ressemeadura natural: efeitos sobre a estrutura de plantas, produção de forragem e de sementes

RESUMO: O objetivo deste estudo foi avaliar o efeito de diferentes níveis de ressemeadura natural de azevém anual (Lolium multiflorum Lam.), bem como, doses suplementares de nitrogênio sobre a estrutura de plantas, produção de forragem e de sementes. Os níveis de ressemeadura

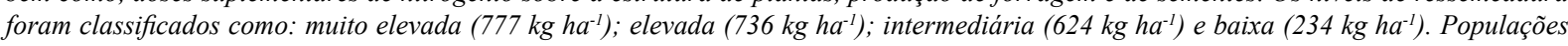
oriundas destes níveis foram fertilizadas com zero, 20.25, 40.50, and $60.75 \mathrm{~kg} \mathrm{ha}^{-1}$ de nitrogênio, aplicado de forma suplementar após duas desfolhas. Maiores niveis de ressemeadura propiciaram maior colheita de forragem e maior uniformização da estrutura da vegetação. A quantidade de perfilhos férteis e o número de sementes por planta foram beneficiados pela combinação de elevada ressemeadura e aplicação de nitrogênio. Apesar de influenciar a uniformização e a quantidade de forragem obtida em duas desfolhas, os niveis de ressemeadura natural, muito elevada e baixa não diferiram entre si na produção de sementes no ano subsequente. Todavia, acréscimo linear para esta mesma variável foi verificado com avanço suplementar da adubação nitrogenada. Em pastagem de azevém anual proveniente dos níveis baixo e intermediário, a produção de massa seca total é acrescida linearmente com os níveis de fertilização avaliados no presente trabalho.

Palavras-chave: Lolium multiflorum Lam., ressemeadura natural, doses de nitrogênio, componentes de rendimento de sementes.

\section{INTRODUCTION}

Italian ryegrass (Lolium multiflorum Lam.) is used as a cover crop in winter. In addition to being used for fodder and seeds, its high biomass protects the soil by supplying straw for soil cover, favoring the adoption of a subtropical crop-livestock system (MORAES et al., 2014; PETERSON et al., 2019).

Italian ryegrass established naturally by self-seeding, which is traditionally, the method of choice in integrated no-tillage systems, has important outcomes such as reduced production cost being 
among the most notorious. However, the success of the activity depends on practices that involve the management of defoliation, which is necessary to guarantee sufficient seed yield as to not compromise the establishment of the subsequent pasture (EVERS \& NELSON, 2000; BARTH NETO et al., 2014).

Generally, defoliation is employed during the vegetative stage in order to minimize impacts on seed yield and maintain straw production (CUNHA et al., 2016). However, if the reproductive tillers are exposed to decapitation, which is a condition frequently observed in southern Brazilian fields, significantly reduces pasture establishment in the following year (BARTHOLOMEW \& WILLIANS, 2009). Moderate defoliation not only garanttees sufficient seed yield for the proper establishment of the pasture, but also reduces soil compaction problems when compared to intense grazing and is shown to be beneficial for the development of summer crops (AMBUS et al., 2018).

Seed densities much higher than those recommended for the establishment of pastures, along with the absence of defoliation, may lead to intense competition among plants with a reduced number of tillers, which consequently leads to persistence and efficiency in the use of available resources (SIMIĆ et al., 2009; TERNUS et al., 2018).

In a stand with a low rate of self-seeding, the application of nitrogen may compensate for the presence of an inadequate establishment. Nitrogen (N) is a determining factor in seed yield in grasses and frequently used in trials that evaluate ryegrass seed yield (SIMIĆ et al., 2012). Accruals in the number of fertile tillers and seed yield are often observed in the presence of nitrogen fertilization (KOERITZ et al., 2015).

Thus, the present study aimed to verify the effects of the combination of self-seeding levels (provided by defoliation levels carried out in the previous year) with additional nitrogen rates on plant structure, biomass and seed production of Italian ryegrass cultivar BRS Ponteio.

\section{MATERIALS AND METHODS}

The study was carried out in an experimental area located in the town of Capão do Leão, Rio Grande do Sul State, Brazil (31 ${ }^{\circ} 80^{\prime} \mathrm{S}$ and $52^{\circ} 40^{\prime} \mathrm{W}$, altitude $13 \mathrm{~m}$ ). The soil, according to STRECK et al. (2008), is a Solodic Eutrophic Haplic Planosol. The experimental area, previously used for livestock activity, presented the predominance of native grasses. The soil was plowed once and harrowed twice. During this stage, the soil acidity was corrected, according to the interpretation of the chemical characteristics verified in the soil analysis, obtained using the "Manual de Adubação e Calagem para os Estados do Rio Grande do Sul e Santa Catarina", a manual developed by TEDESCO et al. (2004) for fertilization and liming. To eliminate spontaneous vegetation after soil preparation, two applications of a total action herbicide (gliphosate) were made, one before and the other after Italian ryegrass sowing.

Sowing was performed at a density of 25 $\mathrm{kg} \mathrm{ha}^{-1}$ of viable Italian ryegrass seeds, cultivar BRS Ponteio, procedure carried out in the second half of April, using a direct sowing machine (Semina 3 Model), spaced $20 \mathrm{~cm}$. The meteorological variables of the experimental period are presented in figure 1 . In the first year, conducted and reported by CUNHA et al. (2016), the self-seeding levels were obtained by the different numbers of defoliations, which were composed respectively by the absence of defoliation; one defoliation: plant height from 15 to $7 \mathrm{~cm}$; two defoliations: plant height from $20 \mathrm{~cm}$ to $10 \mathrm{~cm}$; three defoliations: plant height from 30 to $15 \mathrm{~cm}$. The defoliations were carried out with the aid of a reaper binder machine, and the forage obtained in this process was removed manually. In this first year, the experimental area of $1.536 \mathrm{~m}^{2}$ was composed of 16 experimental units, with $88 \mathrm{~m}^{2}$ each, resulting from the presence of four treatments (defoliation levels). In this first stage, the experiment consisted of a randomized complete block design with four experimental units.

Basal and cover fertilization were equal in all defoliation levels. At the end of the productive cycle of the plants, the self-seeding was estimated from the seed harvest, stage that occurred when the seeds presented approximately 35\% moisture. Given the desired moisture of the seeds, the harvest was carried out from eight samples per plot $(50 \times 50 \mathrm{~cm})$, close to the soil. After this stage, the samples were dried in oven with forced circulation until the seeds reached water contents between $10 \%$ and $13 \%$, as proposed by MAIA (1995).

Seed yield in the first year (Figure 2) reveals that the treatment without defoliation produced $777 \mathrm{~kg}$ $\mathrm{ha}^{-1}$ seeds (very high). Yield with one defoliation was $736 \mathrm{~kg} \mathrm{ha}^{-1}$ seeds (high), two defoliations $624 \mathrm{~kg} \mathrm{ha}^{-1}$ (intermediate), and three defoliations $234 \mathrm{~kg}$ seeds ha- ${ }^{-1}$ (low self-seeding), values that constituted the levels of the self-seeding factor. Defoliation levels did not affect the physiological quality of the seeds since the percentage of germination was $89 \%$ for all treatments. Similar condition occurred in 1000-seed weight, 


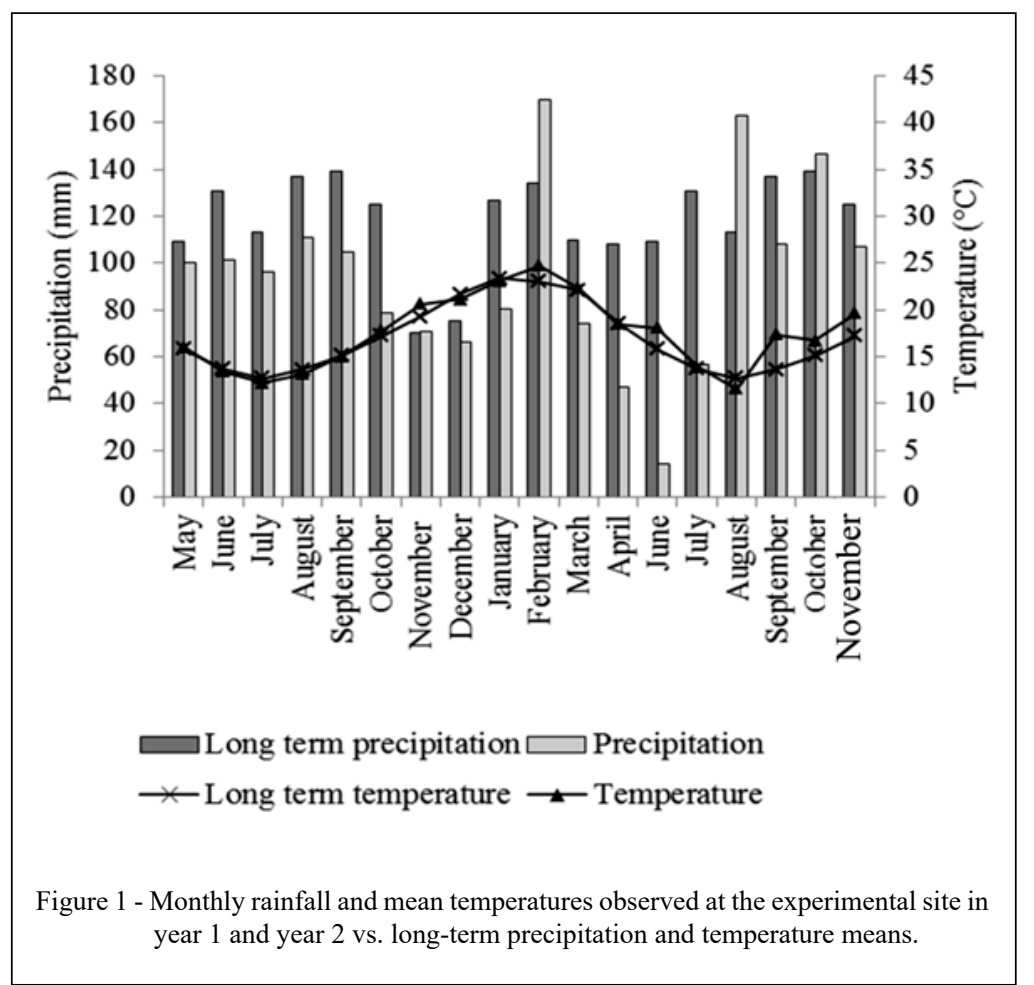

where the mean value of $2.13 \mathrm{~g}$ was verified. After the self-seeding, soybean was introduced by sowing. At the end of the soybean cycle, ryegrass seedlings emerged by self-seeding, which was stimulated by an application of $120 \mathrm{~kg} \mathrm{ha}^{-1}$ of urea $\left(54 \mathrm{~kg} \mathrm{~N} \mathrm{ha}^{-1}\right)$.

Two defoliations were conducted for each level of self-seeding. The first, still in the vegetative stage, took place in early August, while the second was carried out at the end of September in the preflowering stage. Residues of up to six inches after the defoliation were maintained. Four $20 \times 50 \mathrm{~cm}$ plot forage samples were collected. The structural characteristics (plant height, length of completely expanded leaves, number of senesced leaves, number of tillers per plant and length of tillers) were assessed in eight plants per experimental unit, under pre and post-defoliation conditions, totalizing four evaluations. These evaluations were performed according to the "marked tillers" technique detailed by CARRÈRE et al. (1997), in which the completely expanded leaves were measured from its ligule, while the growing leaves were measured from the last visible ligule, according to DAVIES (1993). The height of the last exposed ligula was measured from the soil level and the number of tillers per plant was counted weekly.
The introduction of the second factor under study (nitrogen fertilization) occurred soon after the second defoliation, in addition to the $54 \mathrm{~kg} \mathrm{~N}$ ha $^{-1}$ initially applied. The 16 original plots, consisting of $88 \mathrm{~m}^{2}$, were composed only of plants originating from self-seeding and subdivided into four equal parts $\left(16 \mathrm{~m}^{2}\right)$, which allowed the random distribution of different additional fertilization levels: $0,20.25$, 40.50 and $60.75 \mathrm{~kg} \mathrm{~N} \mathrm{ha}^{-1}$.

Daily monitoring was carried out for the harvesting of seeds using the oven method at 105 ${ }^{\circ} \mathrm{C}$ (BRASIL, 2009). Given the desired moisture of the seeds $(35 \%)$, four samples per subplot $(50 \mathrm{x}$ $50 \mathrm{~cm}$ ) were collected. After the harvest, the seeds were taken to the oven and dried at $32^{\circ} \mathrm{C}$. All drying processes were carried out with the seeds still in the spikelets. Seed yield components (number and length of tillers, number of fertile tillers, and number of seeds per plant) were assessed by randomly selecting eight plants from each subplot.

The experimental design was a randomized complete block design. The subdivided plot design was used for the variables analyzed after the application of nitrogen levels, condition that generated a total of 16 treatments. Levels of self-seeding (as a result of defoliation levels, a fixed effect factor) were main 


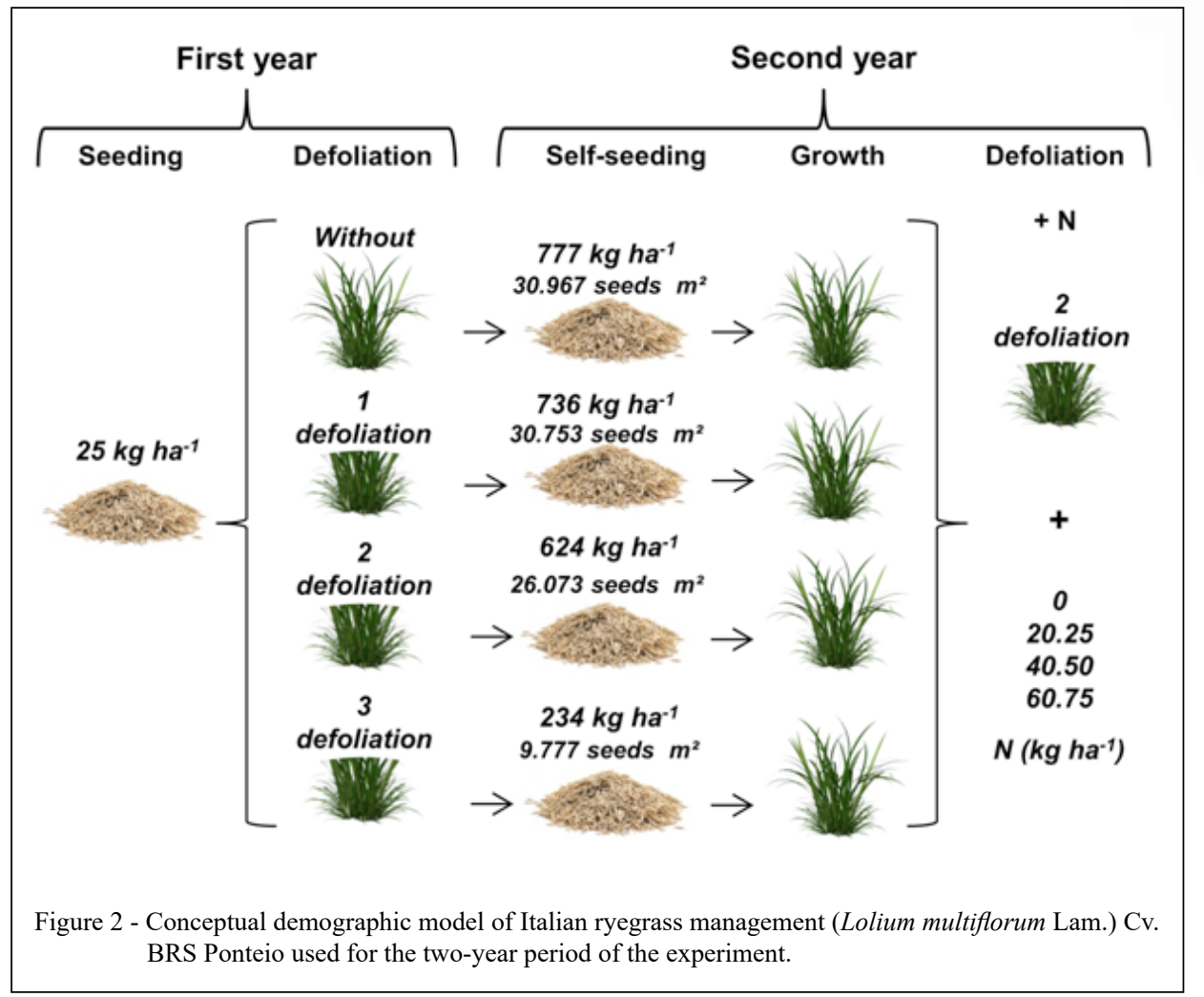

plots and additional $\mathrm{N}$ treatments were sub-plots, with four replicates of each treatment combination. Values were submitted to analysis of variance (ANOVA). In case of significance, the data were submitted to Tukey test $(\mathrm{P}<0.05)$. Linear and polynomial regressions were used in the presence of significance for the nitrogen fertilization factor. All analyses were performed with the statistical software WinStat version 1.0 (MACHADO \& CONCEIÇÃO, 2003).

\section{RESULTS AND DISCUSSION}

Highest self-seeding levels (very high and high) determined better establishment of the Italian ryegrass (Figure 3), which was verified by taller plants and higher forage mass at the first defoliation $(\mathrm{P}<0.05)$. These larger masses and heights were also observed on the second defoliation (Figure $3 \mathrm{e}$ and $3 \mathrm{f}$ ). Higher values of 447 and $561 \mathrm{~kg} \mathrm{ha}^{-1}$ of dry mass were verified at very high in comparison with low self-seeding, in the first and second defoliation, respectively. Intensity and time of the defoliation of Italian ryegrass seem to be determining factors for the establishment of this species via self-seeding. BARTHOLOMEW and WILLIANS (2009) reported that late cuts reduced seed production, seed deposition, 1000 -seed weight and eventual re-establishment of Italian ryegrass seedlings.

Results verified in this study indicated that establishment from self-seeding seems to depend on obtaining an adequate number of seeds per $\mathrm{m}^{2}$. From the 1000-seeds weight $(2.13 \mathrm{~g})$, the levels of defoliation $0,1,2$ and 3 led to the deposition of 30.967 , $30.753,26.073$ and 9.777 viable seeds $\mathrm{m}^{2}$ (Figure 2). BARTHOLOMEW and WILLIANS (2009) reported that numbers of seed heads and seed required to achieve a self-seeded target population of 500 established seedlings $\mathrm{m}^{2}$ ranged from 885 to 5.650 seed heads $\mathrm{m}^{2}$ and 3.360 to 5.850 deposited viable seeds $\mathrm{m}^{2}$, values much lower than those verified even with the use of three defoliations. On the effect of the amount of seed, VENUTO et al. (2004) observed positive effects in increased annual ryegrass sowing rates $(400,800$, 1.200 , and 1.600 viable seeds per square meter) on forage yield. The authors reported a 2.58-fold increase in forage yield when the highest density was compared to the lowest, whereas here this same (very high and low) comparison resulted in a 1.54-fold difference.

Prior to the first defoliation, low self-seeding plants presented a number of tillers $14 \%$ higher, despite 


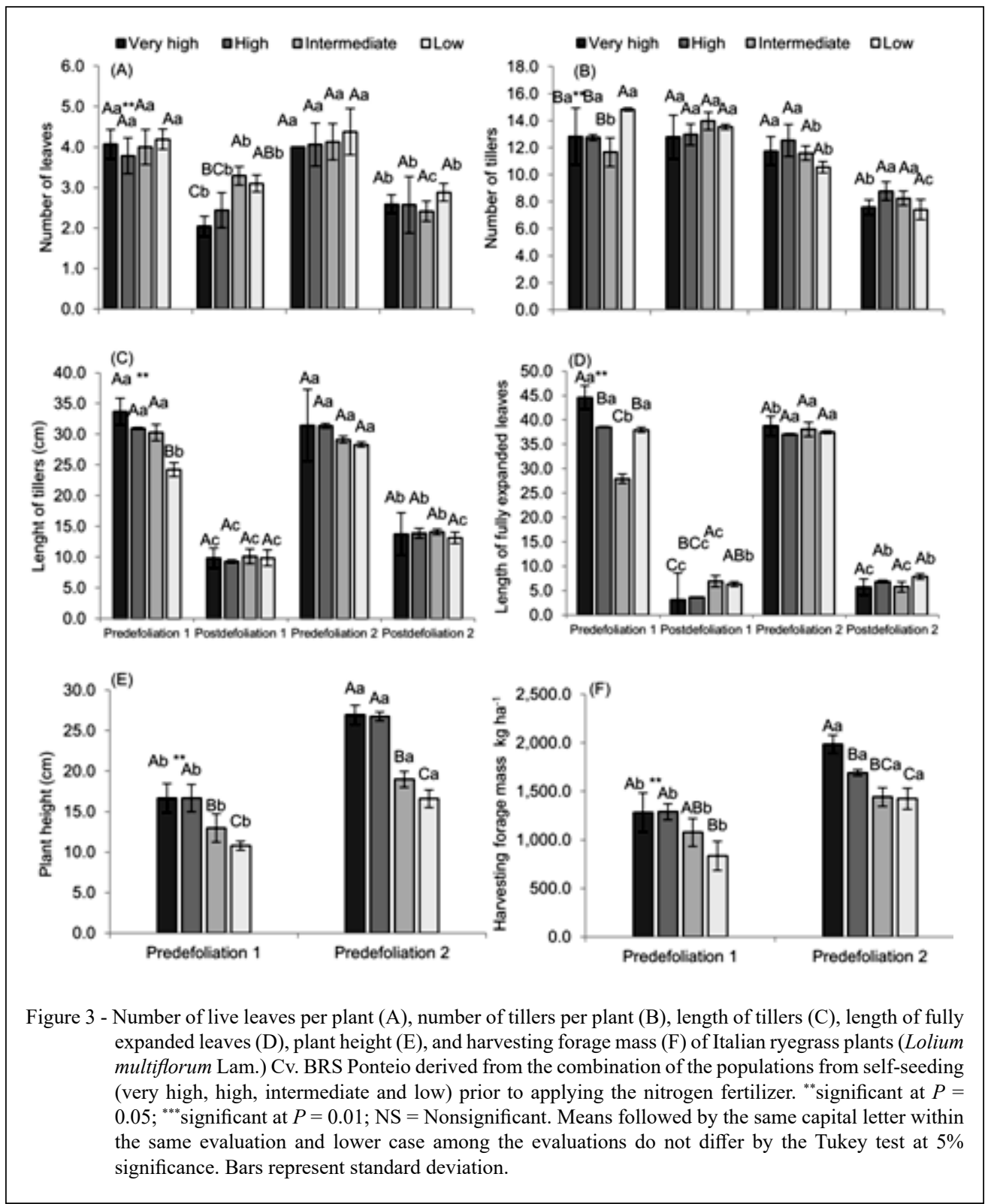

being $28 \%$ shorter in length $(\mathrm{P}<0.05)$ when compared to plants classified as very high (Figure $3 \mathrm{a}$ ). Plants derived from low self-seeding also presented leaf senescence 14\% lower (Figure 4). Conversely, plants from the higher self-seeding levels had superior values in length of completely expanded leaves (Figure 3d).

The self-seeding rate affected the length of the tiller (Figure 3c). SIMIĆ et al. (2009) evaluated the effect of spatial arrangement in Italian ryegrass plants and verified that tiller length, which is similar to the ones observed here, was also affected by sowing rates. Knowingly, DEREGIBUS et al. (1983) observed that tillering in ryegrass is highly influenced by the quality of light since plants develop a higher number of tillers when lit by higher red/red proportions. CASAL et al. (1985) reported that canopy density increases the lower light interception per tiller and the photomorphogenic effect of the low red/red ratio may reduce the production capacity of new tillers. In a review of the physiological processes underlying defoliation, GASTAL \& LEMAIRE (2015) reported that the tiller density and size of the leaves are 


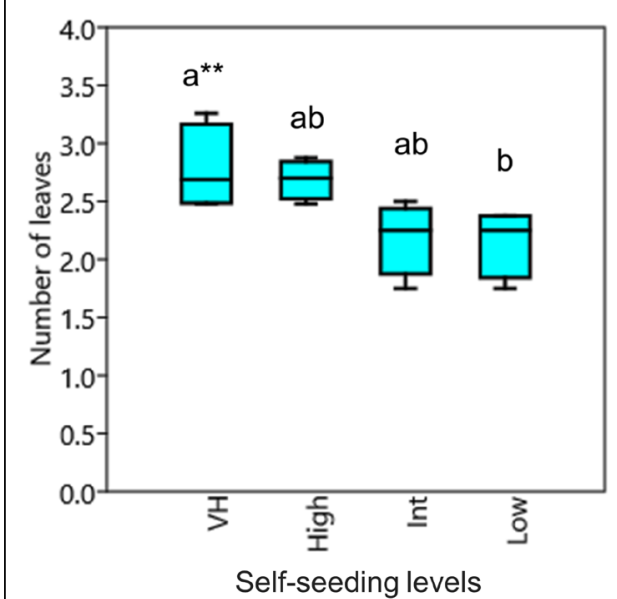

Figure 4 - Number of senesced leaves per tiller in Italian ryegrass (Lolium multiflorum Lam.) Cv. BRS Ponteio prior to the first defoliation in response to selfseeding levels very high ( $\mathrm{VH})$, high, intermediate (Int) and low. ${ }^{* *}$ significant at $P=0.05 ;{ }^{* * *}$ significant at $P=0.01$; NS $=$ Nonsignificant. Means followed by the same letter do not differ by Tukey test at 5\% significance. For each sample, the $25-75$ percent quartiles are drawn using a box. The median is show with a horizontal line inside the box. Minimal and the maximal values are shown with short horizontal lines.

negatively correlated and that there is an inverse relationship between the tiller density and size.

Because of the adaptive strategies of these plants against defoliation, after the second defoliation, a standardization was observed in the number and length of leaves and tillers (Figure $3 \mathrm{a}$ and $3 \mathrm{~d}$ ). This resulted in a certain balance of the structural characteristics, regardless of the seed rate deposited in the soil the previous year. In the standardization of the components, GASTAL \& LEMAIRE (2015) reported that the use of defoliation constitutes an important component to aid in the compensation of tiller size and density. The way defoliation is conducted is a key factor in maintaining an integrated crop-livestock system. In this respect, SCHUSTER et al. (2018) reported that high forage allowance during winter-grazed cover crop caused lower emerged weed flora in subsequent crops.

After the second defoliation, additional levels of nitrogen fertilization were tested and, for the yield components (Table 1), interaction between the factors (self-seeding and nitrogen) was observed in determining the total number of tillers. For this variable, there a significant model $(\mathrm{P}<0.01)$ for each self-seeding level. Linear responses from the $\mathrm{N}$ application were checked at low, intermediate and very high levels, while a quadratic response occurred at the high level. Higher values of fertile tillers were observed for higher levels of self-seeding (Table 1). Significant models $(\mathrm{P}<0.01)$ with maximum points of 7.1 tillers, with 36 and $36.45 \mathrm{~kg} \mathrm{~N} \mathrm{ha}^{-1}$, were obtained at very high and high self-seeding levels, respectively. Benefits of lower grazing intensities were also verified by BARTH NETO et al. (2014). According to these authors, lower intensity provided higher density of tillers, a condition probably reflected in a higher number of reproductive tillers. A linear response $(\mathrm{P}<0.01)$ with increased nitrogen fertilization was verified at low self-seeding level, in which the addition of $50 \mathrm{~kg} \mathrm{~N} \mathrm{ha}^{-1}$ increased approximately two tillers per plant.

As for tiller length (Table 1), there was an interaction between the factors $(\mathrm{P}<0.01)$. At the highest seeding rates, the tillers reached higher lengths with intermediate fertilization. Similar adjustments were reported among the models. The intercepts were 31.2 and $31.8 \mathrm{~cm}$, and the maximum points 35.7 and 36.3 $\mathrm{cm}$ with 38.7 and $33.75 \mathrm{~kg} \mathrm{~N} \mathrm{ha}^{-1}$ for the very high and high self-seeding levels, respectively. At the two lower self-seeding levels, linear responses were observed as a function of the increased nitrogen dosage. Intercepts of 29.7 and $28.2 \mathrm{~cm}$ and slope coefficients between 0.1025 and 0.096 were reported for very high and high self-seeding levels, respectively.

Seed yield per plant, important yield component, presented superior result in high selfseeding level $(\mathrm{P}<0.01)$ for intermediate levels of nitrogen fertilization (Table 1). Intercept of 675.9 seeds per plant and maximum point of 1068.16 seeds per plant were obtained with $33.75 \mathrm{~kg}$ of nitrogen for high self-seeding levels. Linear responses $(\mathrm{P}<0.01)$ in the nitrogen levels were verified for the lower self-seeding levels (intermediate and low). Intercepts of 620 and 449 seeds per plant and slope coefficients of 4.52 and 6.05 were observed, in order that the application of $50 \mathrm{~kg}$ of nitrogen determined yields of 567 and 302 seeds per plant for the intermediate and low self-seeding rates, respectively (Table 1). Part of the findings from this study for performance components were also reported by SIMIĆ et al. (2009), who, when studying the effects of sowing rates and spacing factors on ryegrass italicum, concluded that a high sowing rate is preferable in order to maximize seed yield in the first year of production.

The evaluation of Italian ryegrass seed yield (Table 2) shows isolated effect of the factors studied $(\mathrm{P}<0.01)$. In the self-seeding factor, higher 
Table 1 - Total number of tillers, number of fertile tillers, length of tillers and number of seeds per plant determined at the end of the Italian ryegrass (Lolium multiflorum Lam.) cv. BRS Ponteio cycle, result of the combination of factors self-seeding (low, intermediate, high and very high) and $\mathrm{N}$ fertilization $\left(0,20.25,40.5\right.$, and $\left.60.75 \mathrm{~kg} \mathrm{~N} \mathrm{ha}{ }^{-1}\right)$. ${ }^{* *}$ significant at $P=0.05$; ${ }^{* * *}$ significant at $P=0.01 ; \mathrm{NS}=$ Nonsignificant. ns represents absence of significance.

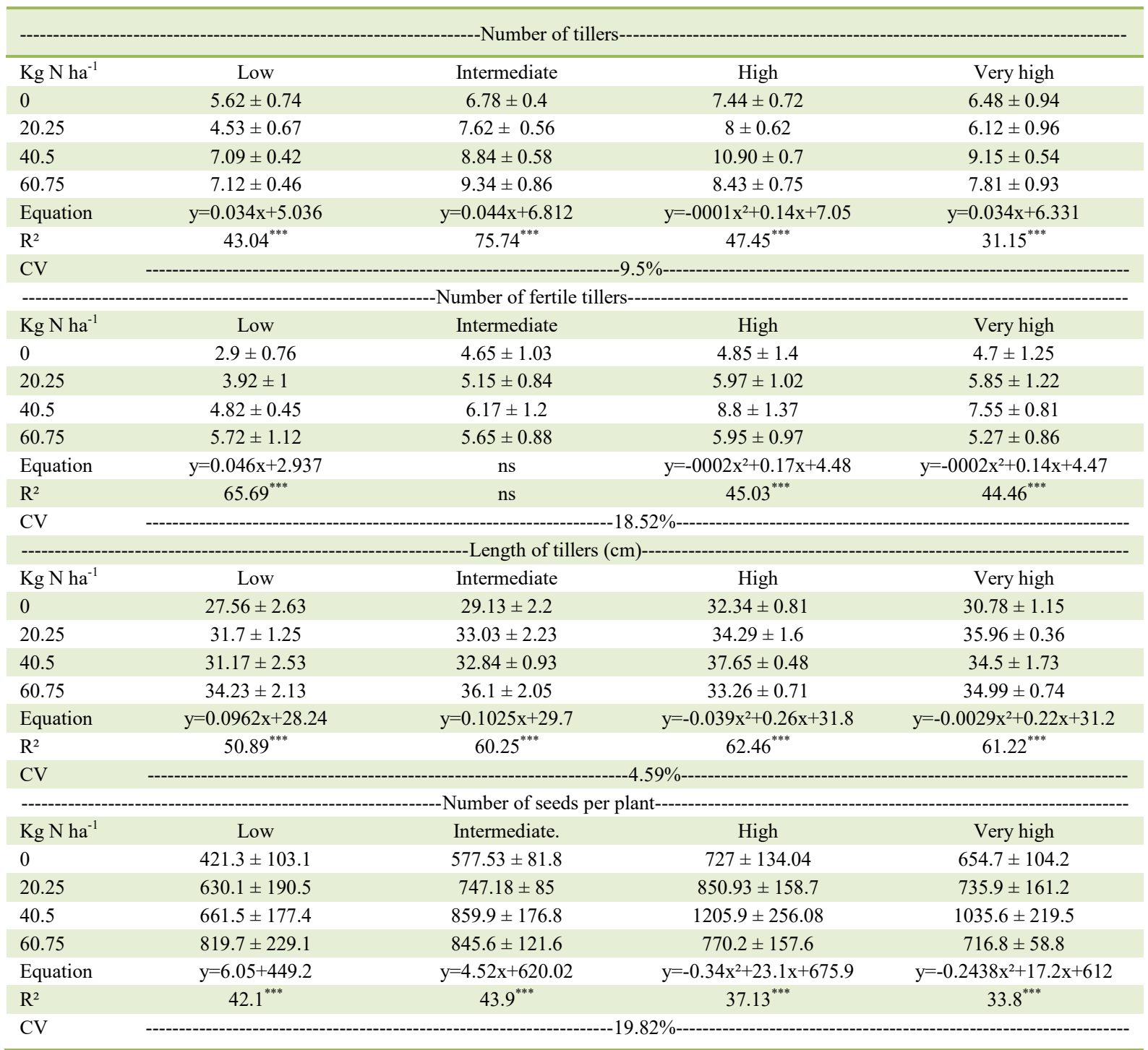

seed production was verified at very high level (609 $\left.\mathrm{kg} \mathrm{ha}^{-1}\right)$, significantly higher than at the intermediate level $\left(458 \mathrm{~kg} \mathrm{ha}^{-1}\right)$. Linear increase in seed yield was observed with increasing levels of the nitrogen fertilization (Table 2). The intercept was $432.1 \mathrm{~kg}$ $\mathrm{ha}^{-1}$ and the slope coefficient was 3.7468, that is, an increase of $3.75 \mathrm{~kg}$ of ha' $\mathrm{h}^{-1}$ seeds occurred with the addition of $1 \mathrm{~kg} \mathrm{~N} \mathrm{ha}^{-1}$. Results obtained by VLEUGELS et al. (2017) showed that the maximum seed yield in Italian ryegrass was reached at a total available $\mathrm{N}$ of $141 \mathrm{~kg} \mathrm{~N} \mathrm{ha}^{-1}$. SIMIĆ et al. (2012) also assessed the benefits of nitrogen for the production of Italian ryegrass seeds. However, the authors observed that the application of $50 \mathrm{~kg} \mathrm{~N} \mathrm{ha}^{-1}$ at the onset of tillering was ideal for seed production considering the environmental conditions. Higher application rates of $\mathrm{N}\left(100\right.$ to $\left.150 \mathrm{~kg} \mathrm{ha}^{-1}\right)$, according to the same authors, had no impact on seed yield.

There was interaction among factors for total dry mass (Table 2). In lower self-seeding levels, nitrogen fertilization promoted a linear increase in values of this same variable. In low and intermediate, 
Table 2 - Seed yields $\left(\mathrm{kg} \mathrm{ha}^{-1}\right)$ and total dry mass $\left(\mathrm{kg} \mathrm{ha}^{-1}\right)$ of the Italian ryegrass (Lolium multiflorum Lam.) cv. BRS Ponteio cycle, result of the combination of factors self-seeding (very high, high, intermediate and low) and $\mathrm{N}$ fertilization $(0,20.25,40.5$, and $60.75 \mathrm{~kg} \mathrm{~N}$ ha-1). ${ }^{* *}$ Significant at $P=0.05 ;{ }^{* * *}$ significant at $P=0.01$; NS $=$ Nonsignificant. Values followed by the same letters are not significantly different $(\mathrm{P}=0.05)$ based on a Tukey's test.

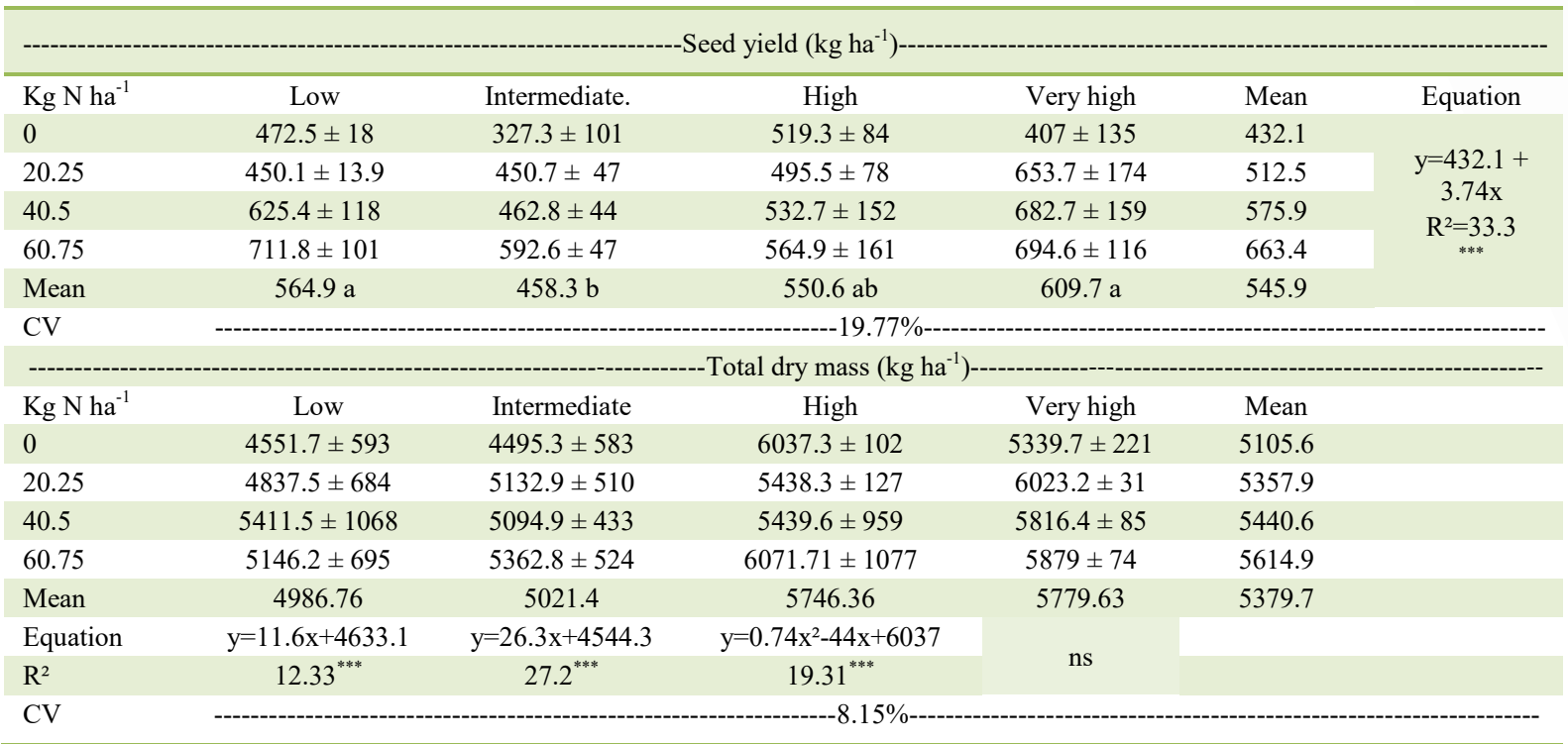

the application of $1 \mathrm{~kg} \mathrm{~N}^{-1}$ promoted increases of 11.6 and $26.3 \mathrm{~kg}$ of dry mass $\mathrm{ha}^{-1}$, respectively. Quadratic response occurred with the nitrogen fertilization at high level, while absence of adjustment was observed at the highest level of self-seeding (very high). The linear increases in total dry mass observed with nitrogen fertilization at lower self-seeding levels indicate that this element can be beneficial when a greater number of defoliations are made in the previous year. Linear response to $\mathrm{N}$, as seen in lower self-seeding levels, is constantly checked in grasses. In a recent study with cold season species that have potential for cover crop, BALKCOM et al. (2019) observed that levels of up to $90 \mathrm{lb} \mathrm{N} \mathrm{ac}{ }^{-1}$, which represents approximately $101 \mathrm{~kg} \mathrm{~N} \mathrm{ha}^{-1}$, provided a linear gain of biomass.

\section{CONCLUSION}

Higher self-seeding (both without defoliation and with a single defoliation) promote better pasture establishment and performance when implemented after soybean crop. However, even the lowest self-seeding rate (after three defoliations $234 \mathrm{~kg}$ of seeds ha ${ }^{-1}$ ) enables, in the following year, seed production similar to the obtained in the area of maximum self-seeding. Nitrogen stands out as the most important factor to determine the seed yield in the post self-seeding phase (ratio of $3.74 \mathrm{~kg}$ of seeds per $\mathrm{kg} \mathrm{ha}^{-1}$ of supplemental nitrogen applied after defoliation). In Italian ryegrass pasture from lower self-seeding levels, the total dry mass is improved linearly with the advance of nitrogen fertilization.

\section{ACKNOWLEDGMENTS}

This study was financed by the Coordenação de Aperfeiçoamento de Pessoal de Nível Superior - Brasil (CAPES) - Finance Code 001

\section{DECLARATION OF CONFLICT OF INTERESTS}

The authors declare no conflict of interest. The founding sponsors had no role in the design of the study; in the collection, analyses, or interpretation of data; in the writing of the manuscript, and in the decision to publish the results.

\section{AUTHORS' CONTRIBUTIONS}

$\mathrm{AB}, \mathrm{CESP}$ and $\mathrm{AM}$ contribute to conception and design of the experiment. AB, BBR, CIS-C and ASS worked in acquisition of data, or analysis and interpretation of data. CESP and GSB worked on interpretation of data and review of the manuscript.

Ciência Rural, v.50, n.6, 2020. 


\section{REFERENCES}

AMBUS, J. V. et al. Changes in composition and functional soil properties in long-term no-till integrated crop-livestock system. Geoderma, n.330, p.232-243, 2018. Available from: <https:// pubag.nal.usda.gov/catalog/5970448>. Accessed: Mar. 15, 2019. doi: 10.1016/j.geoderma.2018.06.005.

BALKCOM, K. S. et al. Oat, rye, and ryegrass response to nitrogen fertilizer. Crop, Forage \& Turfgrass Management, v.5, n.1, p.1-6, 2019. Available from: $<\mathrm{https}$ ://dl.sciencesocieties. org/publications/cftm/abstracts/5/1/180073 > . Accessed: Dec. 09, 2019. doi: 10.2134/cftm2018.09.0073.

BARTH NETO, A. et al. Italian ryegrass establishment by selfseeding in integrated crop-livestock systems: Effects of grazing management and crop rotation strategies. European Journal of Agronomy, v.57, p.77-83, 2014. Available from: $<$ https://prodinra. inra.fr/record/274802>. Accessed: Feb. 20, 2019. doi: 10.1016/j. eja.2014.04.005.

BARTHOLOMEW, P. W.; WILLIAMS, R. D. Establishment of Italian ryegrass (Lolium multiflorum Lam.) by self-seeding as affected by cutting date and degree of herbage removal in spring in pastures of the southern Great Plains of the United States, Grass and Forage Science, v.64, n.2, p.177-186. 2009. Available from: $<$ https://onlinelibrary.wiley.com/doi/abs/10.11 11/j.1365-2494.2009.00682.x>. Accessed: Apr. 20, 2019. doi: 10.1111/j.1365-2494.2009.00682.x

BRASIL. Regras para Análise de Sementes. Brasília: MAPA/ ACS, 2009. 399p.

CARRÈRE, P. et al. Tissue turnover within grass-clover mixed swards grazed by sheep. Methodology for calculating growth, senescence and intake fluxes. Journal of Applied Ecology, v.34, p.333-348, 1997. Available from: <http://www.jstor.org/ stable/2404880?seq=1\#page scan tab contents $>$. Accessed: Nov. 10, 2018. doi: $10.2307 / 2404880$.

CASAL, J. J. et al. Variations in tiller dynamics and morphology in Lolium multiflorum Lam. vegetative and reproductive plants as affected by differences in red/far-red irradiation. Annals of Botany, v.56, n.4, p.553-559, 1985. Available from: $<$ https://academic.oup. com/aob/article-abstract/56/4/553/251909>. Accessed: Nov. 25, 2018. doi: 10.1093/oxfordjournals.aob.a087040.

CUNHA, R. P. et al. Relationship between the morphogenesis of Italian ryegrass cv. 'BRS Ponteio' with forage and seed production. Ciência Rural, v.46, n.1, p.53-59, 2016. Available from: $<$ http://www.scielo.br/scielo.php?pid=S010384782016000100053\&script=sci_arttext $>$. Accessed: Nov. 10, 2018. doi: $10.1590 / 0103-8478 \mathrm{cr} 20150296$.

DAVIES, A. Tissue turnover in the sward. In: DAVIES, A.; BAKER, R.D.; GRANT, S.A.; LAIDLAW, A.S. Sward Measurement Handbook. London: British Grassland Society, 1993, p.183-216.

DEREGIBUS, V. A. et al. Effects of light quality on tiller production in Lolium spp. Plant Physiology, v.72, n.3, p.900-902. 1983. Available from: <http://www.plantphysiol.org/content/72/3/900. short>. Accessed: Nov. 01, 2018. doi: 10.1104/pp.72.3.900.

EVERS, G. W.; NELSON, L. R. Grazing termination date influence on annual ryegrass seed production and reseeding in the southeastern USA. Crop Science, v.40, n.6, p.1724-1728. 2000. Available from: <https://dl.sciencesocieties.org/publications/cs/ abstracts/40/6/1724>. Accessed: Mar. 10, 2019. doi: 10.2135/ cropsci2000.4061724x.

GASTAL, F.; LEMAIRE, G. Defoliation, shoot plasticity, sward structure and herbage utilization in pasture: review of the underlying ecophysiological processes. Agriculture, v.5, n.4, p.1146-1171, 2015. Available from: <https://www.mdpi. com/2077-0472/5/4/1146>. Accessed: Apr. 10, 2019. doi: 10.3390/ agriculture 5041146

KOERITZ, E. J. et al. Seeding rate, row spacing, and nitrogen rate effects on perennial ryegrass seed production. Crop Science, v.55, n.5, p.2319-2333, 2015. Available from: $<$ https:// dl.sciencesocieties.org/publications/cs/abstracts/55/5/2319>. Accessed: Mar. 18, 2019. doi: 10.2135/cropsci2014.02.0130.

MAIA, M.S. Secagem de sementes de azevém anual (Lolium multiflorum Lam.) com ar ambiente forçado. 1995. 108f. Tese (Doutorado em Ciências) - Curso de Pós-Graduação em Ciência e Tecnologia de Sementes, Universidade Federal de Pelotas.

MACHADO, A.A.; CONCEIÇÃO, A.R. Sistema de análise estatística para windows. WinStat. Pelotas: UFPel, 2003. Versão 2.0.

MORAES, A. et al. Integrated crop-livestock systems in the Brazilian subtropics. European Journal of Agronomy, v.57, p.49, 2014. Available from: <https://www.sciencedirect.com/science/ article/abs/pii/S1161030113001457>. Accessed: May, 05, 2019. doi: 10.1016/j.eja.2013.10.004.

PETERSON, C. A. et al. Winter grazing does not affect soybean yield despite lower soil water content in a subtropical croplivestock system. Agronomy for Sustainable Development, v.39, n.26, 2019. Available from: <https://link.springer.com/ article/10.1007/s13593-019-0573-3\#citeas $>$. Accessed: Mar. 20, 2019. doi: 10.1007/s13593-019-0573-3.

SCHUSTER, M. Z. et al. Effects of crop rotation and sheep grazing management on the seedbank and emerged weed flora under a no-tillage integrated crop-livestock system. The Journal of Agricultural Science, v.156, n.6, p.810-820, 2018. Available from: <https://www.cambridge.org/core/journals/ journal-of-agricultural-science/article/effects-of-crop-rotationand-sheep-grazing-management-on-the-seedbank-and-emergedweed-flora-under-a-notillage-integrated-croplivestock-system/ A5C39CB3B6BC1D3A5AA1BC9FF4EE1DA1>. Accessed: Mar. 01, 2020. doi: 10.1017/S0021859618000813.

SIMIĆ, A. et al. The impact of seeding rate and inter-row spacing on Italian ryegrass for seed in the first harvest year, Turkish Journal of Agriculture and Forestry, v.33, n.5, p.425-433. 2009. Available from: <https://journals.tubitak.gov. tr/agriculture/abstract.htm?id=10445>. Accessed: May, 25, 2019. doi: $10.3906 / \operatorname{tar}-0812-12$.

SIMIĆ, A. et al. Response of Italian ryegrass seed crop to spring nitrogen application in the first harvest year. African Journal of Biotechnology, v.11, n.26, p.6826-6831. 2012. Available from: $<$ https://www.ajol.info/index.php/ajb/article/view/102097>. Accessed: Feb. 07, 2019. doi: 10.5897/AJB11.4240.

STRECK, E.V. Solos do Rio Grande do Sul. Porto Alegre: EMATER/RS-ASCAR. 222 p. 2008.

Ciência Rural, v.50, n.6, 2020. 
TEDESCO, M. et al. Manual de adubação e de calagem para os Estados do Rio Grande do Sul e de Santa Catarina. Porto Alegre: Comissão de Química e Fertilidade do Solo - RS/SC, v. 10,400 p. 2004.

TERNUS, R.M. et al. Qualidade de sementes de azevém anual e seus impactos no estabelecimento inicial em diferentes densidades de semeadura. Archivos de Zootecnia, v.67, n.258, p.186-192, 2018. Available from: <https://www.uco.es/ucopress/az/index. php/az/article/view/3653/2248>. Accessed: Feb. 15, 2019. doi: 10.21071/az.v67i258.3653
VENUTO, B. C. et al. Impact of seeding rate on annual ryegrass performance. Grass and Forage Science, v.59, n.1, 8-14, 2004 Available from: <https://onlinelibrary.wiley.com/doi/abs/10.11 11/j.1365-2494.2004.00397.x>. Accessed: Jan. 20, 2019. doi: 10.1111/j.1365-2494.2004.00397.x.

VLEUGELS, T. et al. Seed yield response to $\mathrm{N}$ fertilization and potential of proximal sensing in Italian ryegrass seed crops. Field Crops Research, v.211, p.37-47, 2017. Available from: <https:// www.sciencedirect.com/science/article/pii/S0378429016308802>. Accessed: Mar. 30, 2019. doi: 10.1016/j.fcr.2017.06.018. 